\title{
Provençalism vs Petrarchism: Notes on the Neapolitan Development of the Lyric Genre in the Renaissance. The Case of Cariteo and Serafino Ciminelli
}

It is not uncommon in the study of literature, especially at the end of a research project, when one is called to summarize the most meaningful elements of the field investigated, to realize that the conclusions resemble other conclusions and that the map of the territory just explored has contours very similar to those of other maps drawn in the past. The end of a research project then, may become the beginning of the next one, involving a comparison between the two "maps" presenting close affinities. A new project of this kind promises to reveal more on the essence of the cultural phenomena of the original study; specifically, it promises to reveal what critics often refer to as "roots" and "sources." To the philologist nothing seems to be more precious than such findings, and this is why the comparison for him may become a search for precise correspondences in terms of themes, language and style. But there is at least another type of critic, more adventurous, who is interested in "roots" and "sources"; he is not out to prove anything, he doesn't indulge in technical analysis, he doesn't look for proofs; instead, he looks for affinities in the cartaceous world of human imagination in order to recognize the brotherhood of writers living centuries away but still attached to the same archetypal structures, may they be stories (fabualae), symbols or literary genres. The ultimate object of these critics is to understand the literary experience as an expression of a world which is in fact a whole organism unified by the same dreams and desires. One such critic, and probably the best, is Northrop Frye. I owe to his wholistic vision of literature the confidence to write the present paper, which would have otherwise presented unsurmountable problems and scattered conclusions as a piece of historical and 
philological criticism.

A research project that I completed recently regarded the development of lyric poetry in the early 17 th century. To the majority of critics this particular period, traditionally defined as "The Age of Marino," was identified by its insistence upon a somewhat exaggerated search for the new and the marvellous. Marino's most quoted line "È del poeta il fin la meraviglia," echoed by Chiabrera's intention to "cercar, come Colombo, nove vie o affogare" (xxvi) has been seen as the emblem of Seicento's poetry. But an old and forgotten study by Alessandro d'Ancona has clearly shown that precise correspondences with this "new poetry" can be found in the courtly literature of the late 15th century, especially in the Neapolitan environment (151-237). And from here, then, to the songs of the Provençal troubadours, the link is pretty clear and documented. I intend to explore these affinities bringing to light some aspects of the lyric development in the Renaissance.

After this prosaic preamble on the critical approach I favour and on the object of my paper, I would like to state the path I will follow in the next pages and the conclusions it will lead to. I will discuss some key elements of Provençal poetry as they reappear in the Neapolitan lyric production of the 15 th century (the Aragonese period). I will also compare the mentioned elements of the lyric poetry of Quattrocento with some strikingly corresponding features of early Seicento poetry. The focal points of reference for the lyric poet in the late $\mathrm{XV}$ century, at least in the Neapolitan milieu, seemed to have been Provençalism on the one side and Petrarchism on the other. ${ }^{2}$ Are these categories only historical categories? Are they something that pertains only to that particular period in the development of Italian literature? I think that they represent two more complex and far reaching structural moments in the continuous flow of ideas and ideals. Petrarchism, I maintain, may be seen as representing the established form—or truth, when espoused to Neoplatonism-or also the "classical" point of reference for a cold and artificial poetry, abstract from reality and based on direct imitation; whereas Provençalism could be considered the emblem of that tendency to move towards a visceral and immediate expression of feelings, and towards a poetry that favours the "realistic" representation of sensual and sexual desires. 
$* * * * *$

There are at least four well recognizable elements of Provençal origin in the Neapolitan lyric poetry of the XV century: 1. Realism of representation bordering on open sensuality; 2. Lack of organization and narrativity in the structure of the collections of poems (canzonieri); 3. Musical accompaniment of the lyrics by a lute or any other string instrument of the time; 4 . An extraordinary abundance of paralogism, plays on words, alliterations, paronomasias and other typical rhetorical figures of Baroque literature.

It is with Cariteo that the link between vernacular lyric poetry and Provençal literature appears evident and revealing. One must notice, first of all, that the addressees of his very numerous lyrics were in fact the "cortigiani" of the Aragonese circle in the late years of the 15th century in Naples. An important difference with Petrarch's Canzoniere comes immediately to mind: unlike Petrarch who is always himself, behind the first person singular of his rime, with his abstract thinking about love, death, time and glory, Cariteo's "I" is in fact a "We," a subject representing the people who share certain beliefs and who participate in the same erudite, elegant and very gregarious lifestyle. Important as this element may be, it is in fact a characteristic of the entire Petrarchism, in the broadest sense, and it does not appear to be very useful in the particular analysis of the Neapolitan poets. We shall turn then, again, to the four elements listed above, but not without mentioning that Cariteo's Petrarchism was essentially and consciously a matter of language and style, ${ }^{3}$ and not a matter of substance as it was meant to become with Pietro Bembo. ${ }^{4}$

The subject of Cariteo's canzoniere is his declared love for a lady by the name of Luna, an unusual name which is clearly a señal: a first sure sign of Provençalism in the poet. ${ }^{5}$ The occasion for each lyric was the cortese conversatione at the court of Ferrante and of his successors where Cariteo was an important dignitary (Pèrcopo $\mathrm{xv}$-lvii). Pèrcopo repeatedly insists on the wide distance separating the poet from Petrarch. One of the key elements of differentiation is a new humanization of the woman inspiring Cariteo's lines:

La sua donna ha, oltre quella sua natural freddezza, quel senso pratico e un certo scetticismo,- cosí proprio e comune a tutte le donne!-il quale 
le fa prendere in gioco tutte le smanie dell'adoratore platonico: una volta, anzi, essa gli dice chiaro e tondo di non credergli affatto. Ella non può, non sa immaginare un amore cosí disinteressato: chi dice d'amar tanto una donna, ha qualche fine, qualche scopo da raggiungere. (lxvii)

And there is no doubt on what the final objective of the poet would be. Here is what he says in a "commiato" to his song:

Canzone, ormai ti tace,

Poi che non trova pace-l'alma trista

Vàtene in quel beato-e casto lecto, Basa il candido pecto-e le mammelle, Et l'altre parte belle,-ove Cupido

Sôl albergar, come nel proprio nido! (429)

These things, of course, can only happen in a dream; and in fact the erotic dream (which will become a common stock situation in the canzonieri of the 17 th century), often is recalled to allow for a contemplation of the physical beauty of the unreachable woman:

"Candido sonno"

... Per tua mercé dormendo contemplai

Quella beltade e quel soave ascoso

Candor, che nel mio cor sempre reluce.

Vidi quel che non spero veder mai;

Ringratio te, che fusti piú pietoso,

Che quella mia celeste e alma luce. (16-17)

But the poet cannot live forever with such a continuous sense of frustration, and at times he explodes in an open manifestation of sheer misogyny: the woman is repeatedly called "donna crudele," "fera, ingrata e dura;" the poet even promises to destroy love, which is destroying him, in this remarkable strambotto:

Vivano gli amanti in lieta sorte

Ch'io stutarò, morendo, il foco ardente;

L'ultimo mal bisogna ch'io supporte,

Per troppo amore ad chi d'amor non sente;

$\mathrm{Ma}$, nanzi il mio morir, gridando forte,

Io sfogarò la doglia tra la gente;

Maledicendo ad chi mi dié la morte,

Ad tal che li sia pena eternalmente! (442-443)

Another aspect of Cariteo's collection of rime that clearly reveals its non-Petrarchan, but Provençal nature is the arrangement of the 
lyrics which does not follow an all-encompassing general design. In Petrarch we have the rime in vita followed by the rime in morte ending with the Preghiera alla Vergine, the point of arrival of a long journey recalling Dante's itinerary. But we have nothing of this kind in Cariteo Rime, where there is instead a close affinity with the loose organization of lyrics of the scanty troubadours' collections. In Cariteo's canzoniere there is neither a beginning, nor a middle nor an end: the poetic situations are independent from one another (or from one thematic group of lyrics to another). Every piece seems to be folded onto itself, presenting a meditation on a topic without possibility of developments. That which comes to mind, in this regard, is the wonderful and famous couplet of Guillaume IX d'Aquitaine:

Totz lo joys del mon es nostre,

dompna, s'amduy nos amam. ... (Cento liriche provenzali 4)

This self-centered perspective, which I see as an effect of the selfimposed lack of continuity of narration, is therefore also expressed in the single poems. It often corresponds here to the sharp focusing of a situation and to its analysis resulting in a pure paralogism. There is a block, in other words, which is not resolved in an all-encompassing Neoplatonic dream of perfection, but in a "concettoso, ghiribizzoso e luccicante" (D'Ancona 186) argumentation about the cruelty of love and about the disastrous effects of the "innamoramento," in the lover as well as in the loved one. This is a feature that will reappear in identical form in the lyrics of the XVII century. The following sonnet by Cariteo, in fact,

Voi, Donna, \& io per segni manifesti

Andremo insieme a l'infernal tormento,

Voi per orgoglio, io per troppo ardimento,

Ché vagheggiare osai cose celesti;

Ma perché gli occhi miei vi son molesti,

Voi più martíri havrete, io piú contento,

$\mathrm{Ch}$ ' altra che veder voi gloria non sento,

Tal, ch' un sol lieto fia fra tanti mesti.

Ch' essendo voi presente a gli occhi miei,

Vedrò nel mezzo inferno un Paradiso,

Che 'n pregio non minor che 'l cielo havrei.

Et, si dal vostro sol non son diviso,

Non potran darmi pena i spirti rei:

Chi mi vuol tormentar, mi chiuda il viso! (122)

pleased so much Marino, that he re-wrote it: 
Donna, siam rei di morte. Errasti, errai, Di perdon non son degni i nostri errori: Tu, ch' avventasti in me sí fieri ardori, Io, che le fiamme a sí bel sol furai.

Io, ch' una fera rigida adorai, Tu, che fosti sord' aspe a' miei dolori, $\mathrm{Tu}$, nell'ira ostinata, io negli amori, Tu pur troppo sdegnasti, io troppo amai.

Or la pena laggiú nel cieco averno Pari al fallo ci aspetta. Arderà poi

Chi visse in foco, in vivo foco eterno.

Quivi, s'Amor fia giusto, ambeduo noi A l'inferno dannati, avrem l'inferno

Tu nel mio core, ed io negli occhi tuoi. ${ }^{6}$

From the lack of a unifying structure, a common feature in Provençal collections, to the artificial and paralogic style, the link is direct and obvious; the absence of a design leads to an inner development of the poem, where we see new structures of words ("foco," "inferno") becoming prominent over old patterns of meanings (love, damnation).

On the last point of my analysis, regarding the musical accompaniment to the lyrics, I can only point to Percopo's findings:

Chariteo, oltre a conoscere bene l'arte del canto, era anche compositore di musica, come Serafino Aquilano ed altri rimatori della fine del quattrocento. (ccci)

In conclusion, Alessandro D'Ancona's following comment on the poetry of Cariteo (born in Barcellona and transplanted in Naples where he thrived at the Aragonese Court), remains of fundamental importance notwithstanding its outdated aesthetic pronouncements:

. . La Catalogna era divenuta l'ultimo rifugio della gaja scienza e de' certami floreali: e l'aura che veniva d'Italia si mescolava con quella che spirava dalla Provenza, facendo una temperie molle, tiepida e come di stufa, atta ad educare soltanto fiori di mera apparenza, e frutti senza sapori, ma leggiadri all'occhio. Gli ultimi esempj della forma provenzale artificiosissima, congiunti colle imitazioni petrarchesche, generarono una poesia, cui il genio particolare del paese comunicava un certo che di tumido e di pettoruto. È un gongorismo anticipato, che il Cariteo venendo in Italia esagerò, anticipando fra noi le svenevolezze del marinismo. (189)

The Provençal roots of Cariteo, then, appear to be well established, 
especially when we consider yet another element, of historical importance, of his poetic life. It is a well documented fact that Cariteo was in possession of a Libro dei poeti limosini, a comprehensive anthology of Provençal literature (Pèrcopo ccxviii-ccxxvii and Debenedetti 23-24, 215-16). Apparently the poet translated amply from it and was particularly fond of the lyrics of Folquet de Marseilla, famous for his artificial and elaborate style.

In considering the intrinsic value of the poetry of Serafino Aquilano, the other important exponent of what I referred to as Neapolitan Provençalism, one has to take into account that still very varied is the opinion of the critics on the literary value of his work. Mario Menghini, whose 19th century edition of Serafino's sonnets is still a necessary point of reference, maintained that the poet was definitely more inspired and talented than most of his contemporaries including Cariteo; Giovanni Getto, on the other end, in a 1946 article, shows exactly the opposite view. (Menghini viii-ix, Getto 56-57). More recently we have witnessed a renewal of interest for Serafino's work; the most important contributions have come from Barbara BauerFormiconi, author of a study including an edition of the strambotti, and especially from Antonio Rossi, who has produced the most accurate and researched study on the poet and is presently preparing a complete edition of his works. Whatever the position of the critics may be, the association of Serafino with Cariteo appears to be a solid one with the points of contact being the four elements I described above in illustrating the case of Cariteo's Provençalism.

Just as I have said for Cariteo, Serafino's debt to Petrarch's language and style is an obvious one. But if we look at the development of the poetic situations in Petrarch and Serafino we see that the two poets could not be farther apart. Let's consider, again, the fundamental concepts of Petrarch: love, death, time and glory; in Serafino they lose much of their importance until they become only verbal expressions and are manipulated in a never-ending, paralogistic game; love does not surrender to death, time is never seen as the power that conquers death, and glory is only pursued for its immediate effects; it is, in fact, only fame among his contemporaries that Serafino is interested in. And a great fame he obtained among all the writers of his time; it is to them that we owe the preservation of the poet's works, which he never cared to publish during his life. 
In reviewing now Serafino's position in regard to the four Provençal elements of poetics already noted in Cariteo, I would recall, first of all, that sensuality and realism of representation are the most evident traits of his style. To be sure, his biographical data themselves are very revealing in this regard; he was a real troubador, a famous composer and performer welcomed in every Italian court of the time. There is a certain anxiety in his never-ending pilgrimage from court to court, from woman to woman, that has never been taken too seriously by his critics. It is only by associating him with the Provençal troubadours, with their "psychotic" concern over merces, ioi and deport, that we may get a glimpse of his final artistic objective. And therefore, when we realize with D'Ancona-who elaborates facetiously on the facts reported by Vincenzo Calmetathat

Non ebbe in suoi poemi alcuno particolare amore per oggetto, perché in ogni loco dove si trovava, faceva più presto innamoramento, che pigliar casa a pigione. (D'Ancona 172, Calmeta 1-32)

it is obviously the serious anxiety camouflaged under the frivolous activity that we have to study in order to understand the nature of Serafino's character.

The continuous lack of satisfaction anguishes the poet who, for this reason, very often alternates hyperbolic praises of madonna with harsh comments on her cruelty. What is important to realize here is that the satisfaction sought by the poet is not simply the return of his love; we have, in fact, some situations in which madonna surrenders her body and soul, yet the poet refuses to sing the "joy" of his "paradise." In sonnet number 57 (in Menghini's enumeration) he observes that he will not praise madonna who has returned his love, because he loves her too much and is afraid that Fortune, "Fortuna [che] al ben sempre minaccia," could threaten his happiness (Ciminelli 95); in the subsequent sonnet, he invites madonna to enjoy his love by remembering the good times spent together, "Ch'altra dolcezza al cor, donna, non sente / Che recordarsi de' diletti assai." It is interesting to note that in both compositions the poet uses the word infermo (ill) referring to himself, and he also talks of medicar (to cure) in order to signify that his condition of lover is in fact a disease. The cure, we see, is all in the exercise of the imagination of the poet who describes various effects of his "unfulfillable" desires. 
This is the reason why, when madonna returns his love, he promptly establishes a barrier that allows him to love her from a distance. The poetic situation is perfectly Provençal in nature: Folquet de Marseilla, echoing Bernart de Ventadorn, wrote that he lived well only when the anguish and pain of love killed him. ${ }^{7}$ The powerful and famous oxymoron was amply used by Serafino, who once wrote, "io vivo morto" (Ciminelli 99) and became a common expression in the lyric poetry of the 17th century of which one of the most famous example is perhaps the following by Marino in his "Canzone dei baci”: “. . . l'anima amica ... / baciando l'altra ch'a baciar la 'nvita, / alfin ne more, e quel morir è vita" (27-28). Just like Cariteo, then, Serafino too has the tendency to write about his dreams, and it is exactly because the dream allows him to be close to "madonna" and yet sets her at a certain distance with the awakening:

Quella che suol da me lontano starse

E qui venuta in sogno a consolarmi,

E quando in lei piacer parea pigliarmi,

Io strinsi el vento, e lei col sonno sparse. (Ciminelli 98)

The particular "illness" of the poet, we soon realize, dictates that both proximity and distance be necessary, and this is the reason for which recurring themes such as the gloves of madonna, her ring, her books and even her little dog, become very important centres of reference for the poet. He approaches these items as reflections of the final, but necessarily unreachable, object of his desire. The screen of inanimate objects, however, does not limit, but rather enhances the realism of representation: we have a "ring," for instance (one of the most common themes in Serafino's lyrics), that having been so long in the hands of madonna has touched her all over " ... ognor toccavi lei per ogne lato" (91) and has also been in her mouth, when used to seal letters (92). The realism of Serafino, then, is always to be found in a description of something remembered (when referred to the past) or dreamed of and desired (when referred to the future); it is never a realism of the "here and now." This type of representation obviously locks the time of the narration and leads to a very limited possibility of development of the poetic situations. A first immediate consequence of such fixed-focus imagery is the impossibility of aligning the poet's rime with a logical design of, say, "innamoramento," "amore" and "morte," or any other progressive 
structure.

Had Serafino lived into the first decades of the new century, dominated by the rigidly structured Petrarchism of Bembo, he probably could have tried to give a certain order to his collection of lyrics as, in fact, Cariteo did; ${ }^{8}$ but I think it would have resulted in an awkward operation. As his editors, in early Cinquecento soon found out, the only possible criteria of organization of Serafino's rime in a book could be the generic distinction of forms (sonetti, strambotti, egloghe, capitoli etc.) and the aggregation of the most recurring themes, such as l'anello, il libretto, l'uccellino, il cagnolino etc. (Rossi 11-24). It is without surprise, then, that one comes to realize that when the Neoplatonic ideals of love-which had become predominant in the Petrarchism of the Cinquecento-were questioned by a renewal of poetic interest for realism and sensuality, ${ }^{9}$ the new canzonieri are arranged by genres and themes, as we can see in the pioneering and most important lyric collection of the Baroque age, the Lira, by Giovan Battista Marino. ${ }^{10}$ From realism of representation, and from lack of narrative development of the poetic situation, to the artificial and affected style, the link is very obvious, as we have already seen discussing Cariteo. The poetic situations are repeated over and over again with no other development than an internal, linguistic one. To put it in the simplest terms, the facts remain the same but the words change; and the changing of the words imply a continuous experimentation with new and unusual connotations of old and trite metaphors.

Serafino's musical talent, as it was incorporated into his lyrical production, remains now to be discussed. Angelo Colocci, his enlightened apologist, had this to say to the early critics who tried to turn the poet's singing into a limitation of his talent:

Diranno che la pronuntia li dava gratia; confessaremo in questo haver superato se stesso. Li concedono el proferir singulare, ma che cercava concordar le parole al leuto per piú imprimerle nello animo delle genti $\&$ per hor infiammar hora remectere, come Gracco ne' senati la sua lyra adaptava. Dico che ... el Seraphin per haver dato modo \& da imprimere e da exprimere in rime le passione d'amore, piú ch'alcun altro mai per adietro sarà da esser celebrato. (Colocci 27)

There are several considerations possible regarding the fusion of sound and meaning in the poetic word; I shall insist only on the less 
technical and most unequivocal one. The "singing" of Serafino's poems, as Colocci puts it, is functional in capturing the attention of the listeners. We sense, then, the presence of an audience that shares the poet's insights and feelings in his performances; such an audience was that of the courts of course, where love and poetry were discussed, cultivated and, through the poet, represented in the variety of their manifestations. It is this openness of communications in the hortus conclusus of the court that, I submit, associates Serafino's poetry to that of the troubadours. Just like his Provençal predecessors, in fact, Serafino would sing madonna's praise, ask for a reward, "adimandar mercede"(54), for his service, "servitù" (41), but never mention her name in front of his audience, "a dir suo nome a me non lice" (63). Elements of this kind do not exist in Petrarch where, notwithstanding the initial address dictated by the lyric convention, "Voi ch'ascoltate in rime sparse il suono," it is to a public of readers rather than listeners that the poet refers.

Perhaps G. B. Marino, so similar in poetic character to Cariteo and Serafino, didn't even suspect that in his Lira the spirit of the troubadours was finding new life again, but in the recurring cycles of history the pattern of the Poesia cortigiana in the early XVII century had reappeared more enticing than ever. The small Renaissance courts had disappeared, but the poetic seeds had found fertile ground in the newly funded academies and in the numerous circles of dignitaries around clerical or civil authorities.

University of Toronto

\section{NOTES}

1 See the famous 33rd "fischiata," reprinted in all anthologies of Seicento poetry. A critical edition of all Marino's farciful poems is still lacking, but the original texts have already been re-established by Vassalli.

2 The particular meaning I attribute to these terms is explained later in the article. It should be remembered, however, that the most influential book on love and poetry of the Renaissance, Pietro Bembo's Asolani, was published only in 1505, which means that the Petrarchism of the late Quattrocento is considerably less dogmatic in its language and themes than that of the next century.

3 Cariteo's Petrarchism, as the editor of his Rime observed, aimed mainly at the reproduction of the elaborate and artificial aspects of Petrarch's style: "Il Petrarca-dice De Sanctis-non sempre scrive sotto l'impeto del sentimento ... In questi momenti poco felici ... si abbandona a ragionamenti, che talora 
volgono in sottigliezza o in sofisticherie .... Or il nostro non fece altro che calcar un po' la mano .... E se il Petrarca scherza spesso col nome di Laura, il nostro non poche volte fa lo stesso con quello di Luna" (Pèrcopo cx-cxi).

4 See Baldacci 49-79. On the same point Ferroni writes, “... l'esigenza di un codice sicuro ... di uno schema morale ed umano composto ed atteggiato, trova nel modello petrarchesco (nella lettura fatta dal Bembo e dopo il Bembo) la sua integrale soddisfazione, la sua fonte inesauribile" (14-15).

5 Pèrcopo reviews and discards several hypotheses regarding the mysterious lady sung by Cariteo. He maintains that it is practically impossible to identify her. He is convinced, however, that she was a young Neapolitan of noble birth.

6 The same theme and the same poetic situation appear also in Francesco de Lemene and Eustachio Manfredi, The compositions are compared to Cariteo's original sonnet by D'Ancona (187).

7 See the lyric "Tant $m$ 'abellis l'amoros pessamen" [I like so much the pain of love], in Cento liriche provenzali 151.

8 See Pèrcopo's lix-lxii. For a detailed analysis of the differences between the two separate editions of Cariteo's Rime (1506, 1509), see Fenzi's study.

9 In the XVII century we find a complete reversal of Neoplatonic love, as it appears clearly in this significant sonnet by Scipione Errico. It is titled "Contra l'amor platonico":

Baciami, o Clori, e fa' ch'io goda a pieno

tua leggiadra beltà, tuoi pregi tanti,

e de le grazie tue nel prato ameno

fa' che appaghi a mia voglia i sensi erranti.

$\mathrm{Fa}^{\prime}$ che nel molle tuo nettareo seno gli spirti appaghi languidi e tremanti, e con l'opre da noi scherniti sieno quei che dan legge ai desïosi amanti.

Non vuol filosofia de l'amar l'arte, perché fanciullo Amor non ha costume molto intemarsi ne le dotte carte.

Ceda al tatto la vista, al labro il lume;

il guatar, l'affissar vada in disparte, perché tocca e non mira il cieco nume.

I cite from Ferrero's anthology (788).

10 The "rustico ma nuovo ordine," which Marino announces in the introduction to his 1602 canzoniere is, in fact, this type of internal organization of lyrics. (Rime 2).

\section{WORKS CITED}

BALDACCI, Luigi. "Il Petrarca specchio di vita," Il petrarchismo italiano nel Cinquecento. Padova: Liviana, 1974.

BAUER-FORMICONI, Barbara. Die trambotti des Serafino dall'Aquila. Mun- 
chen: Wilhelm Fink Verlag, 1967.

CALMETA, Vincenzo. "Vita del facondo poeta vulgare Seraphino Aquilano per Vincentio Calmeta composta." Le rime di Serafino de' Ciminelli dall' Aquila. By Serafino Ciminelli. 1-22.

CARITEO [Benedetto Gareth]. Rime. Ed. Erasmo Pèrcopo. 2 vols. Napoli: Accademia delle Scienze, 1892.

CAVALIERE, Alfredo, Ed. Cento liriche provenzali. Bologna: Zanichelli, 1938.

CHIABRERA, Gabriello. "Vita di Gabriello Chiabrera Savonese, da lui medesimo scritta." Delle opere di Gabriello Chiabrera. Vol. 1. Venezia: Stamperia Baglioni, 1805.

CIMINELLI, Serafino [Serafino Ciminelli Aquilano]. Le rime di Serafino de' Ciminelli dall' Aquila. Ed. Mario Menghini. Bologna: Romagnoli-Dall'Acqua, 1894.

COLOCCI, Angelo. "Apologia di Angelo Colotio nell'opere di Seraphino." Le rime di Serafino de' Ciminelli dall' Aquila. By Serafino Ciminelli. 23-32.

D'ANCONA, Alessandro. "Del secentismo nella poesia cortigiana del secolo XV." Studi sulla letteratura italiana de' primi secoli. Milano: Treves, 1805.

DEBENEDETTI, Santorre. Gli studi provenzali in Italia nel Cinquecento. Torino: Loescher, 1911.

FENZI, Enrico. "La lingua e lo stile del Cariteo dalla prima alla seconda edizione dell' Endimione." Studi di filologia e letteratura 1 (1970): 9-83.

FERRERO, Giuseppe Guido, ed. Marino e i marinisti. Milano-Napoli: Ricciardi, 1954.

FERRONI, Giulio, and Amedeo Quondam. La "locuzione artificiosa." Teoria ed esperienza della lirica a Napoli nell' etd del manierismo. Roma: Bulzoni, 1973.

GETTO, Giovanni. "Sulla poesia del Cariteo." Giornale storico della letteratura italiana 123 (1946): 53-68.

GUARDIANI, Francesco. "Marinismo e manierismo nella lirica del primo Seicento." The article is due to appear in Critica letteraria 16 (1987).

MARINO, Giovan Battista. Rime. 2nd part. Venezia: Ciotti, 1602.

MENGHINI, Mario. "Prefazione." Le rime di Serafino de'Ciminelli dall' Aquila. By Serafino Ciminelli. vi-cxviii.

PÈRCOPO, Erasmo. "Introduzione." Rime. By Cariteo. Napoli: Accademia delle Scienze, 1892. xi-ccci.

ROSSI, Antonio. "Edizioni poco note delle rime di Serafino Ciminelli." Studi e problemi di critica testuale 32 (1986): 31-56.

. Serafino Aquilano e la poesia cortigiana. Brescia: Morcelliana, 1980.

VASSALLI, Antonio. "Studio sulle opere burlesche di Giovan Battista Marino." Diss. University of Fribourg (Switzerland), 1975. 